\title{
Executorial Power of Debt Recognition Deed: Statute and Conceptual Approaches
}

\author{
Mustahar ${ }^{*} \quad$ Ahmadi Miru Anwar Borahima Nurfaidah Said \\ Faculty of Law, Hasanuddin University, South Sulawesi, Indonesia
}

\begin{abstract}
Efforts to realize legal certainties in notary science are pursued by perfecting the deed made based on the notarial practice by considering the jurisprudence for cases related to issues of debt recognition. The research combines normative and empirical legal researches. Conducted in Makassar city, South Sulawesi, Indonesia. The results show that pointing the sacred sentence "For Justice Based on the Almighty God" at the heading of the debt recognition deed made by a notary has a meaning an oath to do justice in the process of making the deed so that it cannot only be accountable to interested parties, but must be able to be accountable to the State, society, religion and to God Almighty. The practice of making a debt recognition deed by notary which only puts the manuscript "For Justice Based on the Almighty God" in the heading of the copy of the deed in the form of a Grosse deed of debt recognition and not being placed in the minutes of the deed results resulting in an improper title. Debt recognition that has an executorial title has legal consequences in the form of forced bodies for defaulted debtors, so a high moral awareness is needed for the notary to make the debt recognition deed always acted carefully and fairly to the parties.
\end{abstract}

Keywords: Debt; Deed; Notary; Statute; Legal Certainty

DOI: $10.7176 / \mathrm{JLPG} / 98-28$

Publication date:June 30th 2020

\section{Introduction}

The 1945 Constitution of the Republic of Indonesia as the highest law explicitly stipulates that Indonesia guarantees certainty, order and law protection by uphold truth and justice. ${ }^{1}$ Authentic deed as strongest evidence has an important role in every legal relationship in people lives. ${ }^{2}$ In various business relationships, activities in banking, land, social activities, etc., the need for written evidence in the form of an authentic deed is increasing in line with the growing demand for legal certainty in various economic and social relations, both at the national, regional, and global levels. ${ }^{3}$

The legal uncertainty to the legislation as experienced by the community is due to incomplete legal regulations. Although the issue of legal certainty can be overcome by applying the rule of law by a judge if there is a dispute in court, the court's ruling is often different from the ruling for the same case. One of the regulations which until now have caused legal uncertainty is the regulation of Grosse debt recognition deed as regulated in the legislation. An incomplete arrangement regarding Gross debt recognition deed causes the making of notarial deed is different in practice and there are differences in judge' decisions in judicial practice.

Efforts to realize legal certainties in notary science are pursued by perfecting the deed made based on the notarial practice by considering the jurisprudence for cases related to issues of debt recognition. According to the author, the privilege of a debt recognition deed made by or before a notary because only a debt recognition deed can be given manuscript (irah-irah) for a justice based on the Almighty God, which has the same executorial power as a judge' decision that has permanent legal force. It means that a "product" of notarial deed in the form of a debt recognition deed is truly an extraordinary and special authority because the "product" of notary is equated with a judge' decision, even though debt recognition is not a court ruling. Another privilege, the only authentic deed that can be included in the executorial title is debt recognition deed, which raises the question of what the juridical and philosophical basis of debt recognition deed that causes privilege. ${ }^{4}$

An effort for the notary in exercising his/her position has high integrity and responsible for the world and the hereafter, then before exercising his/her position, a notary must be sworn in. ${ }^{5}$ The importance of a notary' oath, if not done, causes the decision to appoint a notary to be canceled by the Minister. ${ }^{6}$ Oaths are spoken not to the leader but to those you believe in, namely God, it become scared something. This is your personal promise to something

\footnotetext{
${ }^{1}$ Yunus, A., Fitriyani, D., and Taufiq, A. 2020. Uji Proporsionalitas Terhadap Hasil Investigasi Kecelakaan Pesawat: Dimensi Hak Asasi Manusia, Amanna Gappa, 27(2): 122-135

${ }^{2}$ Medyantara, I. S., Husni, L., \& Sudiarto, S. 2019. Grosse Executorial Strength What Is Recognition of Debt in Practice. International Journal of Multicultural and Multireligious Understanding, 6(3), 735-743.

${ }^{3}$ General explanation of Act No. 30 of 2004 concerning the Position of Notary

${ }^{4}$ J. Satrio, 2002 Hukum Jaminan Kebendaan, PT. Citra Aditya Bakti, Bandung, p.15; Compare to Ali, A. 2008. Menguak Tabir Hukum, Ghalia Indonesia, Bogor, p. 36

${ }^{5}$ Article 5 UUJN

${ }^{6}$ Article 6 UUJN
} 
that is religious in nature, and therefore in exercising is based on each belief and as motivations that are far more than mere worldly motivations. ${ }^{1}$

According to the author, for people have confidence in the deed that will be made in accordance with the intended law, it is necessary to analyze deeply about the debt recognition deed from all aspects including how the process of making the deed, the contents of the deed and the conditions for making a debt recognition deed so that it is feasible to be equated with a court ruling that has permanent legal force, so that provide certainty, order and legal protection. This research aims to analyze the meaning of the manuscript (irah-irah) for a justice based on the Almighty God in the debt recognition deed, both in format and its procedural aspect.

\section{Method of Research}

The research combines normative and empirical legal researches. The type of normative legal research is used to analyze the relevant regulations regarding the inclusion of the manuscript for a justice based on God Almighty, whereas empirical legal research is used to analyze efforts to create a more accountable debt recognition deed so that it is worthy to get executorial power. It was conducted in Makassar city, South Sulawesi, Indonesia, as a city with increasingly rapid economic growth in Indonesia. Sampling is done by using stratified sampling technique as a technique that describes precisely the characteristics of heterogeneous populations; therefore the population must be divided into uniform strata. ${ }^{2}$

\section{The Meaning of Manuscript (Irah-Irah) for A Justice Based on Almighty God in the Debt Recognition Deed by the Notary}

Grosse deed is a copy of the deed for debt recognition with the heading of the deed "FOR JUSTICE BASED ON THE ALMIGHTY GOD," which has an executorial power. ${ }^{3}$ The theory of justice from Jhon Rawls states that a fair way to unite different interests is through a balance of interests without paying special attention to the interests themselves. ${ }^{4}$ The principles by which a rational person will choose if he/does does not know his/her position in society, this principle of justice we choose, because people will always act according to their own interests, then we cannot let someone with their interests decide their own problems or cases, so the only way that can be decided about injustice is to imagine a situation where we do not or do not have interests. In this case, there is no other choice but to decide honestly. ${ }^{5}$

According to the author, this provision shows the importance of the sentence "For Justice Based on Almighty God" which if not included in the court's ruling results in the decision being null and void. If the final process of a trial in a court that result in the judge's decision, it is mandatory to include the manuscript (Irah-Irah), there is also a process of making laws within the scope of private law which requires the inclusion of manuscript (IrahIrah), namely the process of making an authentic deed by notary.

The authentic deed on the heading is given the title "For Justice Based on Almighty God", can be executed as a court's ruling that has received definite legal force. Grosse deed as authentic deed has power as a court decision. The given of executorial power on the basis that the official who establishes the rights in the deed has high integrity. ${ }^{6}$

The public official who is given the authority by law to make an authentic deed called debt recognition deed is a notary. Although the deed of debt recognition is not a product of the judicial process, but the deed of debt recognition has same executorial power as a ruling by a judge with permanent legal force (inchracht van gewijde). ${ }^{7}$ Administrative independence by a notary who is free to regulate office financial management is a strong foundation for the notary to do justice to the process of making an authentic deed.

Placing the sacred sentence "For Justice Based on Almighty God" in an authentic deed made by a notary implies that the sentence should be a concern, guidance and spiritual basis for each notary in making a debt recognition deed. Making a deed is certainly not only accountable to the parties or interested parties, but must be able to be accountable to the State, society, religion and the God.

According to the author, if the judge has an obligation in each his/her decisions, then must include the manuscript "For Justice based on the Almighty God", then the notary also has the obligation to write manuscript in each copy of the debt recognition deed if requested by the creditor. Even though the notary is not a judge, but the sentence "For Justice based on the Almighty God" has the same dimension of responsibility as a judge. An effort the notary in exercising his/her position has high integrity and responsible globally and in the hereafter,

\footnotetext{
${ }^{1}$ Ministry of Finance of Republic of Indonesia. Available online at:: https://www.kemenkeu.go.id/publikasi/berita/menkeu-sumpah-jabatanadalah-janji-kepada-tuhan/, accessed on 26 May 2020.

${ }^{2}$ Singarimbun, M., and Efendi, S. 1998, Metode Penelitian Survey, LP3ES, Jakarta, p.162

${ }^{3}$ Article 1 paragraph 11 UUJN

${ }^{4}$ Ilmar, A. 2014. Hukum Tata Pemerintahan. Prenadamedia. Jakarta, p. 51

${ }_{5}^{5}$ Tejaningsih, T, 2016, Perlindungan Hukum Terhadap Kreditor Separatis dan Pemberesan Harta Pailit, FH UI Press, Yogyakarta, p. 43

6 Satrio, 2002, Hukum Jaminan Kebendaan, PT. Citra Aditya Bakti, Bandung, p.15

${ }^{7}$ Harris, F., and Helena, L. 2017, Notaris Indonesia, PT. Lintas Cetak Djaja, Jakarta, p.36
} 
then before exercising his/her position, a notary must be sworn in. ${ }^{1}$ An oath is a declaration given or spoken when giving promises or information keeping in mind the Almighty God, and believes that those who give incorrect information or promises will be punished by Him. Thus, an oath is a religious act used in justice. ${ }^{2}$

A notary must act honestly, thoroughly, independently, impartially, responsible and has principles in exercising his/her position, namely: ${ }^{3}$

1. The principle of equality. The notary must treat anyone equally without distinction. There is no classification or privilege for class, socio-economic or any reason. Even in certain circumstances, the notary is obliged to provide legal services in the realm of notary for free to those who cannot afford it.

2. The principle of trust and confidentiality. The position of notary is a position of trust that carrying the position of a notary as a person who can be trusted in accordance with the oath of office and can keeps confidentiality.

3. The principle of legal certainty, duty to avoid and to prevent any form of an authorized legal practice. Acting as the applicable legal rules will provide certainty to the parties that the deed made before or by the notary is in accordance with the applicable legal rules.

4. The principle of prudence and reasonable beliefs. All evidence shown to the notary is not only examined but also listening to the statements or information of the parties must be done as a basic material to be stated in the deed.

5. The principle of reason. Notary is also a jurist, a legal expert who can provide legal opinion.

6. The principle of proportionality, the duty to avoid and to prevent any unjust and unfair legal practice to exploit any person' disadvantageous legal or otherwise circumstances. The notary must consider based on his/her legal knowledge whether an action can be stated in the deed or not. The notary must prioritize a balance between the rights and obligations of the parties.

7. The principle of professionalism, duty of continuous effort to improve the legal system and justice system. This principle prioritizes the expertise (scientific) of the notary in exercising the duties of his/her position. A notary as a bearer of office must always strive and develop the professionalism of his/her position by always updating with the rules and critical in implementing various regulations in his/her position.

The principles as stated above can also be found and applied to judges in Indonesia based on the Judicial Conduct Guidelines of Judge, which are the reflection on the guidelines that were first coined in the IKAHI Extraordinary Congress IV 1966 in Semarang, in the form of the Indonesian Judge Ethics Code and supplemented again in IKAHI National Conference XIII 2000 in Bandung. And then, it will be followed up at Work Meeting of the Supreme Court the Republic of Indonesian 2002 in Surabaya, which formulates 10 (ten) the Judicial Conduct Guidelines principles. The process of preparing these guidelines was also preceded by an in-depth study which included a similar comparison process set in various countries, including the Bangalore Principles. This Judicial Conduct Guidelines is an elaboration of 10 (ten) principles which include the obligations to behave fairly, honestly, and wisely, act independently, be highly integrated, be responsible, uphold self-esteem, be highly disciplined, behave low heart, and be professional. ${ }^{4}$

In addition to the considerations as mentioned above, the potential and opportunities for notaries to exercising their positions are trustworthy, honest, thorough, independent, impartial, safeguarding their honor, dignity, and responsibility as a notary because in exercising their positions is not given the salary/honorarium by the State, but sourced from the agreement of the parties. The notary honorarium is determined in Article 36 of the UUJN by regulating the maximum limitation of the honorarium based on the economic and sociological value of the deed.

\section{Legal Consequences of Debt Recognition Deed: Statute Approach}

Original letters of mortgages and debt securities as made before a notary in Indonesia and use the words: "For Justice" in the heading, the strength is same as a judge' decision. In exercise such a letter, if it is not fulfilled by peaceful means, then rules can be treated in this section, but with the understanding, that forced body must only be carried out after being allowed by the judge' decision. If the matter of carrying the ruling must be carried out in whole or in part outside the jurisdiction of the district court, the leader of which ordered the ruling, then the provisions of Article 195 paragraph two and the following can be implemented. ${ }^{5}$

Execution of Grosse deed of debt recognition is an execution conducted with an executorial power attached to Grosse deed, when the debtor is declared default or in a state of not fulfilling the achievement at the time specified in Grosse deed, the creditor can request the exercising of direct execution through an application to

\footnotetext{
${ }^{1}$ Article 4 UUJN

${ }^{2}$ Mertokusumo, S. 1988, Hukum Acara Perdata Indonesia, Liberty, Yogyakarta, p.147

${ }^{3}$ Harris, F., and Helena, L., Op.Cit, p.39

${ }^{4}$ Source: http://www.pa-kuningan.go.id/tentang-pengadian/sistem-pengelolaan-pengadilan/pengawasan-dan-kode-etik-hakim, accessed on 4 November 2018

${ }^{5}$ Guidelines of Duties Implementation and Judicial Administration in the Realm of Court, Book II, Edition 2007, the Supreme Court of the Republic of Indonesia, 2012, p.88.
} 
chairman of the district court, direct execution is execution which is done without going through the stages of a civil suit beforehand. ${ }^{1}$

Although a deed has the title "For Justice Based on Almighty God", the judge still has the authority to determine whether the execution of Grosse deed can be granted or not. ${ }^{2}$ Then, it is re-stated that in addition it needs to be reminded that the execution or not a Grosse deed as referred to in Article 224 HIR is the full authority of the judge concerned. These opinions are not a new opinion, but rather rearrange the current opinion which considers that all Gross deed must be implemented. ${ }^{3}$

In principle, the case examination is over if one of the parties gives a comprehensive recognition of the subject matter of the case. If the defendant recognizes purely and unanimously the subject matter of the plaintiff argued, the disputed case is considered to have been completed because with that recognition the legal relationship between the parties has been confirmed and resolved. The judge must accept that recognition as fact and truth. ${ }^{4}$

The legal consequence as sanctions against default debtors who do not carry out achievement based on the debt recognition deed, it can be done forced body after obtains permission from the judge. The threat of reclination in the imprisonment is one of the considerations for the importance of "presenting" God in making each debt recognition deed that distinguishes it from a notarial deed other than debt recognition deed. The goal is that the notary as deed maker is careful, thorough and responsible to the God for the formal truth of debt recognition deed that he/she made and guarantees that what the debtor wants is written in the deed. In addition to the responsibility of a notary as a deed maker, responsibility must also be borne by the debtor who claims to be in debt to the creditor, in order to seriously implement the contents of the deed of debt recognition with a promise before God.

The legal consequences of debt recognition deed by forced body to carry out the achievement obligations are different from the implementation of the agreement or the general statement made by a notary. In general, defaults on agreements have legal consequences or sanctions in the form of fines, compensation or interest payments. Only a debt recognition deed provides more severe legal sanctions if the debtor fails to promise and is regulated separately in the form of a forced body. The results of research in banking, no legal officers know about forced bodies can be done against debtors who do not pay debts when using a debt recognition deed.

Written evidence or a letter is anything that contains reading signs that are intended to pour out heart or to convey thoughts and are used as proof. ${ }^{5}$ Letters as written evidence are divided into 2 (two), namely letters that are deeds and other letters that are not deeds, while the deeds themselves are further divided into authentic deeds and underhanded deeds. ${ }^{6}$

Debt recognition deed are qualified as written evidence with the strength of evidence (bewijskracht) attached to the authentic deed regulated in Article 1870 BW jo. Article 285 RBG is perfect (volledig bewijskracht) and binding (bindende bewijskracht) so that the debt recognition deed made by a notary authentically inherent in the strength of proof, formal and materiil. As the strongest and most complete written evidence, what is stated in a notary deed must be accepted, unless the interested parties can prove the opposite satisfactorily before a court hearing. ${ }^{7}$ Sources of regulation on debt recognition deed can be seen in Chart 1.

\footnotetext{
${ }^{1}$ Dewi, K.K. 2009, Pelaksanaan Pembuatan Grosse Akte Pengakuan Hutang oleh Notaris di Kota Semarang, (Thesis), Faculty of Law, Diponegoro University.

${ }^{2}$ Decision No. 1520/K/Pdt/1984 dated 31 May 1986.

${ }^{3}$ Atmadja, A.K. 1989, in a letter No. 041/098/89/II/UM-TU/Pdt dated on 21 January 1989 that submitted to Winita E. Kusnandar, Kusnandar \& Associates.

${ }^{4}$ Harahap, Y, 2004, Hukum Acara Perdata, Sinar Grafika, Jakarta, p.505

${ }^{5}$ Sudikno Mertokusumo, Op. Cit, p.116

${ }^{6}$ Loc. Cit.

${ }^{7}$ General explanation of UUJN
} 


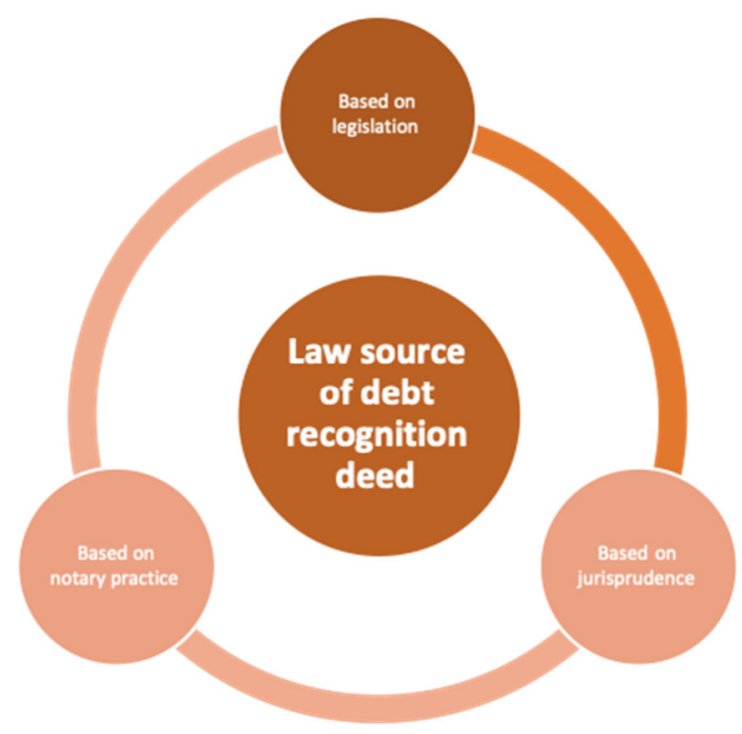

Chart 1. Arrangement sources of debt recognition deed

The privilege of content of debt recognition deed made by a notary is the presence of one-sided debt recognition from the debtor. If seen from the type of evidence, recognition is included in the type of evidence in civil law. The truth contained in a pure recognition is an absolute force, the parties and the judge are bound to accept the truth, the judge must use it as a basis for resolve in making decisions.

In principle, the examination of a case is over if one party gives a comprehensive recognition of the subject matter of the case. If the defendant recognizes purely and unanimously of the main material argued by the plaintiff, it is considered that the disputed case has been resolved, because with that recognition the legal relationship between the parties has been confirmed and resolved. ${ }^{1}$

Debt recognition made before a notary provides the strength of a perfect and binding evidence even though the debt recognition is not the result of a trial process but because the debt recognition is made before a notary as an authentic deed and the notary has the authority to provide a Grosse deed with the manuscript "For Justice Based on God Almighty."

If the contents of the debt recognition deed is one-sided statement (pure recognition) of the amount of debt included in the authentic deed made by a notary, then the debt recognition deed is equated with the recognition in the evidentiary process at the court hearing because in the Grosse deed execution process, the judge no longer assesses the truth of the contents of the debt recognition deed before granting the execution (fiat), but only checking the formal requirements for making the debt recognition deed. Unless the creditor requests a reclination (gijzeling) of the debtor conducting the default, then the implementation of reclination must be through a judge's decision.

The author's opinion is based on the decision of the Supreme Court of the Republic of Indonesia No. $411 \mathrm{~K} /$ Pdt/1991 dated 26 September 1992 in one of the legal considerations that the debt recognition deed arising is based on the presence of a "Credit Agreement". ${ }^{2}$ To know whether or not the court (judge) provides an interpretation of a Grosse deed, first look at the main elements of Article $224 \mathrm{HIR}$, that is, Grosse deed is same as the strength of the decision of judge, if it is carried out if it is not done peacefully, it is applied by order of the Chairman of the District Court (KPN - Ketua Pengadilan Negeri), KPN leads the execution order issued. ${ }^{3}$

Based on this legal construction, it can be said that Article 224 HIR closes the door for KPN to assess the validity of a Grosse deed, which means that KPN must conducting the execution of each Grosse deed submitted to it. Peace is the only reason that can delay or abolish the power of the executive law.

\section{Conclusion}

Pointing the sacred sentence "For Justice Based on the Almighty God" at the heading of the debt recognition deed made by a notary has a meaning an oath to do justice in the process of making the deed so that it cannot only be accountable to interested parties, but must be able to be accountable to the State, society, religion and to God Almighty. The practice of making a debt recognition deed by notary which only puts the manuscript "For Justice Based on the Almighty God" in the heading of the copy of the deed in the form of a Grosse deed of debt recognition and not being placed in the minutes of the deed results resulting in an improper title not given because it is not in

\footnotetext{
${ }^{1}$ Kamsilaniah., Abbas, N., Patittingi, F., and Miru, A. 2018. The Existence of Stage House as Fiduciary Guarantee: Perspective of Horizontal Separation Principle, Journal of Law, Policy, and Globalization, Vol. 75.

${ }^{2}$ Available online at; https://yuridis.id/kasus-hutang-piutang-the-bank-of-tokyo-melawan-debitur-indonesia/, accessed on 9 February 2020

${ }^{3}$ Harahap, H. 2000, Grosse Akta (Suatu Masalah Hukum dari Kongres Ikatan Notaris Indonesia XVII), Varia Peradilan N0. 179 of XV
} 
accordance with Article $224 \mathrm{HIR}$ which regulates that the original mortgage and debt securities made before a notary in Indonesia.

Debt recognition that has an executorial title has legal consequences in the form of forced bodies for defaulted debtors, so a high moral awareness is needed for the notary to make the debt recognition deed always acted carefully and fairly to the parties. More complete regulation is needed regarding the debt recognition deed in the new national civil law, so that it is no longer regulated in the civil procedural law and the Notary Position Law.

\section{References}

Ali, A. 2008. Menguak Tabir Hukum, Ghalia Indonesia, Bogor.

Dewi, K.K. 2009, Pelaksanaan Pembuatan Grosse Akte Pengakuan Hutang oleh Notaris di Kota Semarang, (Thesis), Faculty of Law, Diponegoro University.

Harahap, H. 2000, Grosse Akta (Suatu Masalah Hukum dari Kongres Ikatan Notaris Indonesia XVII), Varia Peradilan N0. 179 of XV

Harahap, Y, 2004, Hukum Acara Perdata, Sinar Grafika, Jakarta

Harris, F., and Helena, L. 2017, Notaris Indonesia, PT. Lintas Cetak Djaja, Jakarta.

Ilmar, A. 2014. Hukum Tata Pemerintahan. Prenadamedia. Jakarta.

Kamsilaniah., Abbas, N., Patittingi, F., and Miru, A. 2018. The Existence of Stage House as Fiduciary Guarantee: Perspective of Horizontal Separation Principle, Journal of Law, Policy, and Globalization, Vol. 75.

Medyantara, I. S., Husni, L., \& Sudiarto, S. 2019. Grosse Executorial Strength What Is Recognition of Debt in Practice. International Journal of Multicultural and Multireligious Understanding, 6(3), 735-743.

Mertokusumo, S. 1988, Hukum Acara Perdata Indonesia, Liberty, Yogyakarta.

Ministry of Finance of Republic of Indonesia. Available online at:: https://www.kemenkeu.go.id/publikasi/berita/menkeu-sumpah-jabatan-adalah-janji-kepada-tuhan/, accessed on 26 May 2020.

Satrio, 2002, Hukum Jaminan Kebendaan, PT. Citra Aditya Bakti, Bandung.

Satrio, J. 2002 Hukum Jaminan Kebendaan, PT. Citra Aditya Bakti, Bandung.

Singarimbun, M., and Efendi, S. 1998, Metode Penelitian Survey, LP3ES, Jakarta.

Tejaningsih, T, 2016, Perlindungan Hukum Terhadap Kreditor Separatis dan Pemberesan Harta Pailit, FH UII Press, Yogyakarta.

Yunus, A., Fitriyani, D., and Taufiq, A. 2020. Uji Proporsionalitas Terhadap Hasil Investigasi Kecelakaan Pesawat: Dimensi Hak Asasi Manusia, Amanna Gappa, 27(2): 122-135. 